\title{
Arachnoid granulations: a rare cause of lytic occipital bone lesion
}

\section{Ziarnistości pajęczynówki: rzadka przyczyna litycznych uszkodzeń kości potylizznej}

\author{
Selin Tural Emon, Metin Orakdogen, Elif Akpinar, Tayfun Hakan, Mehmet Zafer Berkman \\ Haydarpasa Training and Research Hospital, Department of Neurosurgery, Istanbul, Turkey
}

Neurologia i Neurochirurgia Polska 2012; 46, 6: 603-606

DOI: 10.5114/ninp.2012.31606

\begin{abstract}
Arachnoid granulation is often found incidentally in the dural sinuses and skull. It may also enlarge the dural sinus or inner table of the skull. We report a 46-year-old woman who presented with occipital headaches and arachnoid granulations in both transverse sinuses and torcular herophili. Neurological examination was normal. Fundoscopic examination, visual fields and acuity were normal. The headache resolved with medical treatment. No intervention for these lesions was planned. The patient was followed up with magnetic resonance imaging studies.
\end{abstract}

Key words: arachnoid granulation, lytic bone lesion, transverse sinus, headache.

\section{Introduction}

Arachnoid granulation was first described in Dissertatio Epistolaris de Glandulis Conglobatis Durae Meningis Humanae (1705) [1]. An arachnoid granulation can protrude directly into the sinus lumen, adjacent to venous entrance sites, and should not be mistaken for sinus thrombosis [2]. It is arachnoid villi's response to increase in the cerebrospinal fluid (CSF) pressure. After this response, arachnoid villi can be seen with the naked eye as an arachnoid granulation [3]. It provides a pathway from the subarachnoid space into the venous system [2].

\section{Streszczenie}

Ziarnistości pajęczynówki są często spotykane przypadkowo w obrębie zatok żylnych opony twardej i w czaszce. Moga również poszerzać zatokę żylną opony twardej lub blaszkę wewnętrzną kości czaszki. W pracy opisano przypadek 46-letniej kobiety, która zgłosiła się z powodu bólów głowy umiejscowionych w potylicy i ziarnistości pajęczynówki w obu zatokach poprzecznych i w spływie zatok. W badaniu neurologicznym, w tym w badaniu dna oka, pól widzenia i ostrości wzroku, nie stwierdzono nieprawidłowości. Ból głowy ustąpił po leczeniu zachowawczym. Nie planowano interwencji wobec stwierdzonych ziarnistości pajęczynówki. Prowadzono kontrolną obserwację badaniami za pomocą rezonansu magnetycznego.

Słowa kluczowe: ziarnistość pajęczynówki, lityczne uszkodzenie kości, zatoka poprzeczna, ból głowy.

Arachnoid granulations are present in the superior sagittal sinus, torcular herophili, transverse sinus, cavernous sinus, superior petrosal sinus, and straight sinus. The incidence rates of arachnoid granulations were $0.3-24 \%$ in cadaveric and imaging studies [4-7]. Their function is not exactly understood, although cerebrospinal fluid resorption seems to be the probable cause [6]

\section{Case report}

A 46-year-old woman was admitted to the hospital with an occipital headache. Neurological examination

Correspondence address: Dr Selin Tural Emon, Tibbiye cad No: 40, Uskudar, Istanbul, Turkey, phone: + 902163379137 ,

e-mail: turalselin@gmail.com

Received: 10.01.2012; accepted: 8.03.2012 

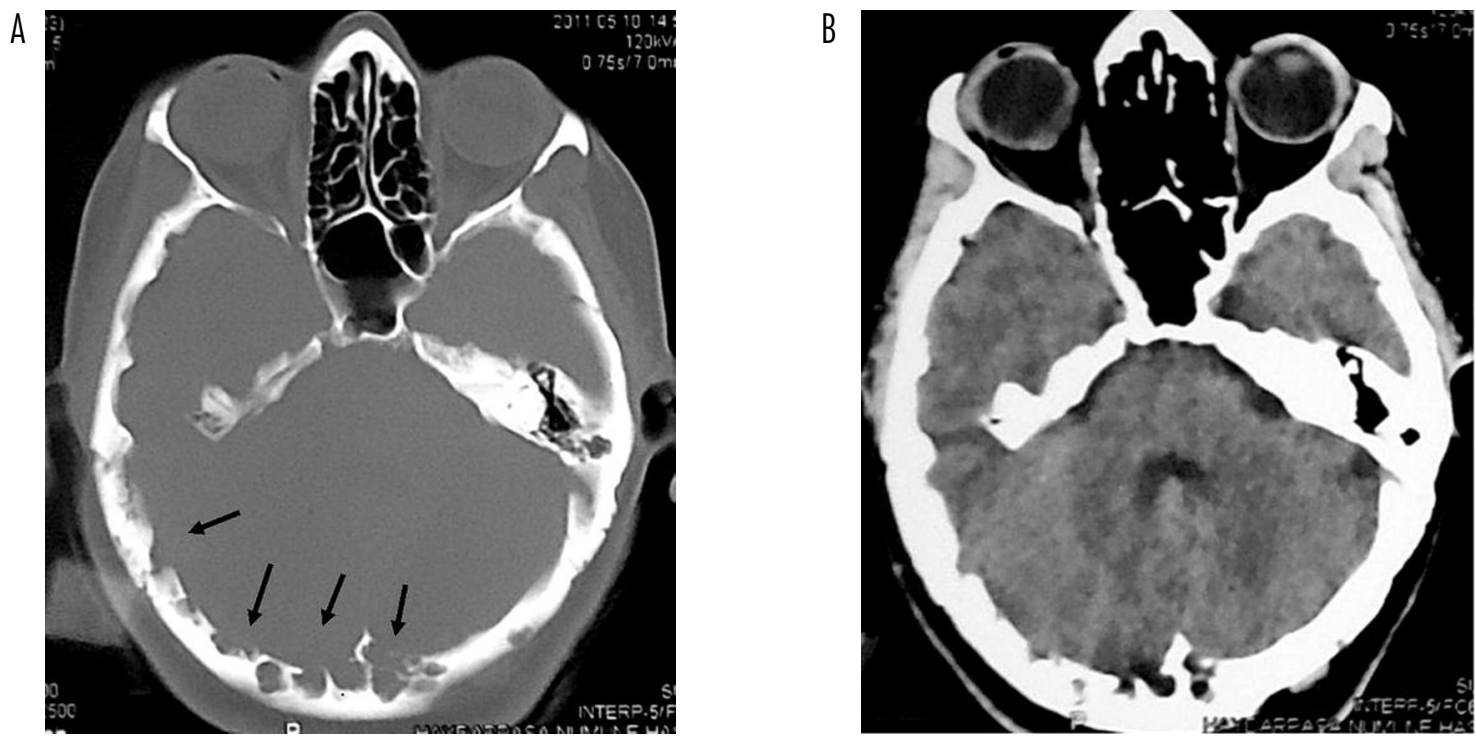

Fig. 1. Axial computed tomography bone window image (A) and axial computed tomography scan (B) show lytic occipital skull lesions (black arrows)

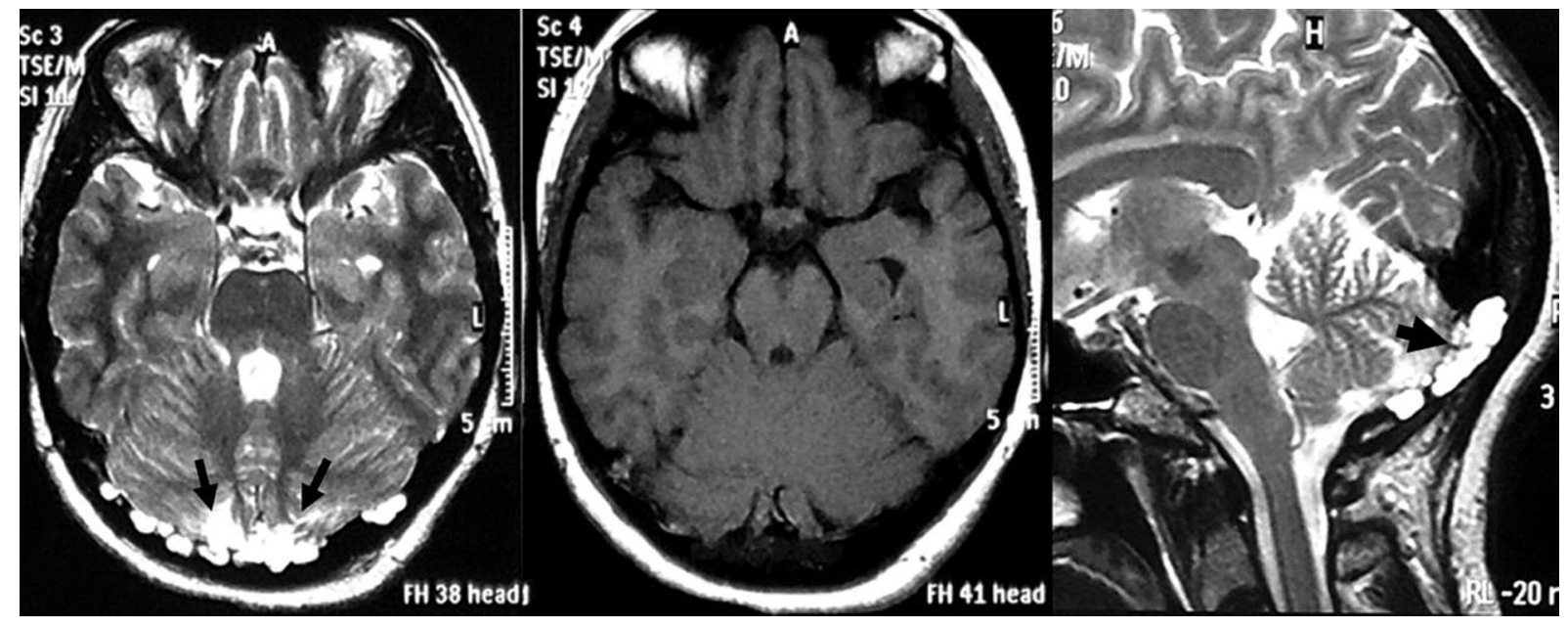

Fig. 2. Axial T1-weighted (A), axial T2-weighted (B) and sagittal T2-weighted (C) magnetic resonance images show arachnoid granulations bilaterally in transverse sinuses and torcular herophili with minimal intrusion. These lesions are isointense with cerebrospinal fluid (black arrows)

was normal. Visual field and acuity were normal. Fundoscopic examination findings were normal. The results of the laboratory tests were within the normal ranges. Magnetic resonance images (MRI) showed occipital uncalcified granulations. These occipital lesions were hypointense on T1-weighted images and hyperintense on T2-weighted images (Fig. 1). On T1- and T2-weighted images, minimal bilateral intrusion to the transverse sinuses, torcular herophili and granulations isointense with CSF were detected. These lesions also caused lytic areas on the inner table of the occipital bone. Brain computed tomography (CT) scan showed multiple lytic areas of the occipital bone (Fig. 2). Lumbar puncture was performed and the pressure was within the normal range. The headache resolved with medical treatment. No intervention was planned and the patient was followed up through MRI studies.

\section{Discussion}

Arachnoid granulations are often discovered incidentally in the sinuses and skull $[8,9]$. Generally, they are asymptomatic, which could probably be explained by their slow growth [10]. The literature shows that the 
common complaint of the patients was headache $[8,10]$, and many patients have neither high CSF pressure nor papilloedema $[8,10]$. Kan et al. [8] measured the patient's intrasinus pressure and ruled out venous hypertension. Arachnoid granulations have rarely been reported to cause symptoms due to venous hypertension secondary to partial sinus occlusion [8]. The most common location was the middle third of the transverse sinus (85.8\%); the next most common site was the lateral transverse sinus [5]. Our patient had arachnoid granulations bilaterally in the transverse sinus and in torcular herophili. We observed minimal intrusion to the bilateral transverse sinus and torcular herophili. Lesions were classified as arachnoid granulations or giant arachnoid granulations in the literature [7]. Giant arachnoid granulations are much larger than normal arachnoid granulations, approximately $10 \mathrm{~mm}$ in diameter [7]. Especially in the elderly (aged $>65$ years), they can reach a remarkable size up to $2.5 \mathrm{~cm}$ or greater in diameter [7]. Arachnoid granulation morphology presents a classically round, clearly defined form [10]. Most of the arachnoid granulations were reported to be spherical or finger-like in shape [11]. Histologically, arachnoid granulations can be classified into two types: single and lobulated type [11]. In our case, arachnoid granulations were lobulated and had a spherical shape. Generally, an arachnoid granulation measures a few millimeters; if they grow sufficiently, they can occlude and enlarge the dural sinus. They can be misdiagnosed as a sinus thrombosis [12]. An arachnoid granulation can cause pressure on the inner table of the skull [13]. Rarely, an arachnoid granulation can erode the outer table [13]. Erosion of the bone is not clinically significant unless it is located near pneumatized parts of the skull [14]. It can lead to CSF leakage [14]. Lee et al. [14] reviewed CT scans of the temporal bone in $1255 \mathrm{pa}-$ tients. They found that $30(2.4 \%)$ of the patients had defects of the posterior wall of the temporal bone and 2 patients had CSF leakage [14]. Erosions are generally in the anterior parietal bone and posterior frontal bone, usually within $3 \mathrm{~cm}$ of the midline $[13,15]$. In our case, erosion was in the occipital bone; this is a rare location.

Differential diagnosis of an arachnoid granulation can be dural sinus thrombosis, meningocele, dermoid, epidermoid, cavernous hemangioma, or meningioma $[3,16]$. Ikushima et al. [3] reviewed $1118 \mathrm{MRI}$ and described FLAIR images of arachnoid granulations. Their signal intensities were similar to CSF on T1- and T2weighted images. The authors concluded that FLAIR images were helpful in differentiating granulations from dural sinus lesions or skull lesions which have similar intensity to that of CSF on $\mathrm{T} 1$ - and T2-weighted ima ges. The signal intensity of the arachnoid granulations in our study were also similar to that of CSF.

The general complaint of patients with arachnoid granulation is headache. Although the mechanism of the patient's headache is not clearly understood, this issue should be investigated. Arachnoid granulations frequently cause erosions in the anterior parietal bone and posterior frontal bone. Unlike what has been reported in the literature, in our case the location of the arachnoid granulations was the occipital bone. Thus, it should be kept in mind that arachnoid granulations might be a rare cause of lytic occipital bone lesion.

\section{Disclosure}

Authors report no conflict of interest.

\section{References}

1. Mamourian A.C., Towfighi J. MR of giant arachnoid granulation, a normal variant presenting as a mass within the dural venous sinus. AJNR Am J Neuroradiol 1995; 16: 901-904.

2. Branan R., Wilson C.B. Arachnoid granulations simulating osteolytic lesions of the calvarium. AJR Am J Roentgenol 1976; 127: 523-525.

3. Ikushima I., Korogi Y., Makita O., et al. MRI of arachnoid granulations within the dural sinuses using a FLAIR pulse sequence. Br J Radiol 1999; 72: 1046-1051.

4. Chin S.C., Chen C.Y., Lee C.C., et al. Giant arachnoid granulation mimicking dural sinus thrombosis in a boy with headache: MRI. Neuroradiology 1998; 40: 181-183.

5. Leach J.L., Jones B.V., Tomsick T.A., et al. Normal appearance of arachnoid granulations on contrast-enhanced $\mathrm{CT}$ and MR of the brain: differentiation from dural sinus disease. AJNR Am J Neuroradiol 1996; 17: 1523-1532.

6. Roche J., Warner D. Arachnoid granulations in the transverse and sigmoid sinuses: CT, MR, and MR angiographic appearance of a normal anatomic variation. AJNR Am J Neuroradiol 1996; 17: 677-683.

7. Lee M.H., Kim H.J., Lee I.H., et al. Prevalence and appearance of the posterior wall defects of the temporal bone caused by presumed arachnoid granulations and their clinical significance: CT findings. AJNR Am J Neuroradiol 2008; 29: 1704-1707.

8. Choi H.J., Cho C.W., Kim Y.S., et al. Giant arachnoid granulation misdiagnosed as transverse sinus thrombosis. $J$ Korean Neurosurg Soc 2008; 43: 48-50.

9. Kan P., Stevens E.A., Couldwell W.T. Incidental giant arachnoid granulation. AJNR Am J Neuroradiol 2006; 27: 1491-1492.

10. Giraud P., Thobois S., Hermier M., et al. Intravenous hypertrophic Paccioni granulations: differentiation from venous dural thrombosis. J Neurol Neurosurg Psychiatry 2001; 70: 700-701. 
11. Arjona A., Delgado F., Fernandez-Romero E. Intracranial hypertension secondary to giant arachnoid granulations. J Neurol Neurosurg Psychiatry 2003; 74: 418.

12. Brunori A., Vagnozzi R., Giuffrè R. Antonio Pacchioni (16651726): early studies of the dura mater. J Neurosurg 1993; 78 : 515-518.

13. Chen F., Deng X.F., Liu B., et al. Arachnoid granulations of middle cranial fossa: a population study between cadaveric dissection and in vivo computed tomography examination. Surg Radiol Anat 2011; 33: 215-221.

14. Apaydin F.D., Yalçinoğlu O., Yildiz A., et al. Arachnoid granulations in the transverse sinuses of a patient with ocular melanoma. J Clin Neurosci 2003; 10: 132-134.

15. Haybaeck J., Silye R., Soffer D. Dural arachnoid granulations and "giant" arachnoid granulations. Surg Radiol Anat 2008; 30 417-421.

16. Rosenberg A.E., O'Connell J.X., Ojemann R.G., et al. Giant cystic arachnoid granulations: a rare cause of lytic skull lesions. Hum Pathol 1993; 24: 438-441. 